Original Research Paper

\title{
Pengelolaan Sampah Plastik Menjadi Produk Bernilai Jual Tinggi di Desa Tuananga Pada Era New Normal
}

\author{
Ida Zuraidah ${ }^{*}$, Isnaini ${ }^{1}$, Resiana $^{2}$, Venny Malinda ${ }^{3}$, Agil Al Idrus $^{4}$

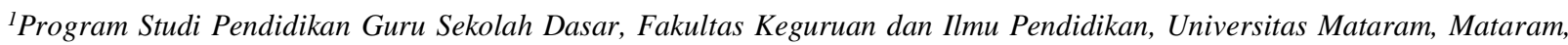 \\ Indonesia \\ ${ }^{2}$ Program Studi Pendidikan Anak Usia Dini, Fakultas Keguruan dan Ilmu Pendidikan, Universitas Mataram, Mataram, \\ Indonesia \\ ${ }^{3}$ Program Studi Pendidikan Bahasa dan Sastra Indonesia, Fakultas Keguruan dan Ilmu Pendidikan, Universitas Mataram, \\ Mataram, Indonesia \\ ${ }^{4}$ Program Studi Pendidikan Biologi, Fakultas Keguruan dan Ilmu Pendidikan, Universitas Mataram, Mataram, Indonesia
}

DOI: https://doi.org/10.29303/jpmpi.v3i2.590

Sitasi: Zuraidah. I., Isnaini., Resiana., Malinda, V., \& Idrus, A. A. (2021). Pengelolaan Sampah Plastik Menjadi Produk Bernilai Jual Tinggi di Desa Tuananga Pada Era New Normal. Jurnal Pengabdian Magister Pendidikan IPA, $4(1)$

\section{Article history}

Received: 02 Desember 2020

Revised: 29 Desember 2020

Accepted: 18 Januari 2021

*Corresponding Author: Ida

Zuraidah, Program Studi

Pendidikan Guru Sekolah

Dasar, Fakultas Keguruan dan

Ilmu Pendidikan, Universitas

Mataram, Mataram, Indonesia

Email:

idhazuraidah9@gmail.com

\begin{abstract}
Jumlah timbulan sampah domestik di Kabupaten Sumbawa Barat pada tahun 2018 sebesar 43.556,81Kg/per-hari (Dinas Lingkungan Hidup dan Kehutanan Provinsi NTB, 2018). Desa Tuananga merupakan salah satu desa yang berada di Kabupaten Sumbawa Barat, tepatnya di kecamatan Poto Tano. Desa Tuananga terletak di pedalaman sekitar pesisir pantai dan jauh dari jalan raya sehingga mempersulit truk pengangkut sampah masuk ke Desa Tuananga, yang menyebabkan sampah terus menumpuk di tempat pembuangan akhir yakni sungai. Hal ini mendorong penulis menjalankan program daur ulang sampah plastik untuk dijadikan barang yang berguna dan bernilai jual melalui program Kampung Lestari sebagai salah satu kegiatan dalam pelaksanaan Kuliah Kerja Nyata (KKN) Universitas Mataram. Produk yang kami hasilkan adalah meja belajar dan pot bunga yang berbahan dasar Plastik bekas. Bahan-bahan yang digunakan untuk memproduksi meja belajar dan pot antara lain: sampah plastik, resin, katalis, pipa besi, dan baut. Alat-alat yang digunakan antara lain: panci, kompor, cetak produk, dan pengaduk. Lokasi pembuatan produk terletak di Desa Tuananga Kecamatan Poto Tano, Kabupaten Sumbawa Barat, NTB dan lokasi pemasaran produk antara lain: Desa Tuananga, Pasar Seteluk, dan Buen Telu. Harga dari produk ini sangat terjangkau oleh kalangan yang ekonominya rendah. Strategi yang digunakan dalam pemasaran atau promosi produk secara online dengan menggunakan sosial media berupa Facebook dan endorse.
\end{abstract}

Keywords: Daur ulang; Sampah plastic

\section{Pendahuluan}

Sampah merupakan salah satu permasalahan yang patut untuk diperhatikan. Sampah merupakan bagian yang tidak dapat terpisahkan dari kehidupan manusia, karena pada dasarnya semua manusia pasti menghasilkan sampah. Sampah merupakan suatu buangan yang dihasilkan dari setiap aktivitas manusia. Volume peningkatan sampah sebanding dengan meningkatnya tingkat konsumsi manusia. Manusia sebagai individu maupun sebagai warga masyarakat mempunyai kebutuhan yang bersifat individual 
maupun kolektif, sehingga selalu ada upaya untuk memenuhi kebutuhan tersebut. Aktifitas manusia dalam upaya mengelola sumber daya untuk memenuhi kebutuhan hidupnya semakin beragam seiring dengan pertumbuhan jumlah penduduk.

Pertumbuhan jumlah penduduk telah mengakibatkan perubahan yang besar terhadap lingkungan hidup. Jumlah penduduk di Kabupaten Sumbawa Barat semakin meningkat dari tahun ketahun. Berdasarkan data BPS, diketahui bahwa jumlah penduduk Kabupaten Sumbawa Barat pada tahun 2016 sebanyak 137.072 jiwa dan meningkat menjadi 144.707 jiwa pada tahun2018-2019 (BPS Kabupaten Sumbawa Barat, 2018-2019).

Peningkatan jumlah penduduk tersebut sebanding dengan peningkatan jumlah konsumsi yang mempengaruhi besarnya peningkatan volume sampah di Kabupaten Sumbawa barat. Jumlah timbulan sampah domestik pada tahun 2018 sebesar 43.556,81 Kg/per-hari (Dinas Lingkungan Hidup dan KehutananProvinsi NTB, 2018). Hal ini menjadi alasan kuat bahwa masalah sampah merupakan masalah utama yang harus dipecahkan baik dalam jangka pendek, menengah maupun panjang.Pemanfaatan sampah harus diprioritaskan sebelum terjadinya pencemaran lingkungan yang mengganggu kesehatan masyarakat. Maka perlu adanya pengelolaan sampah, pengelolaan sampah memerlukan kegiatan yang sistematis, menyeluruh, dan berkesinambungan mengenai penanganan sampah.

Dalam Undang - Undang RI Tahun 2008 Nomer 18 tentang, pengelolaan sampah disebutkan bahwa pengelolaan sampah bertujuan agar menjadikan sampah sebagai sumber daya. Berdasarkan tujuan inilah, maka pemerintah berupaya untuk mengubah pola pikir masyarakat yang masih menggunakan sistem kumpul-angkutbuang sebagi solusi pengurangan sampah. Pola pikir masyarakat diarahkan pada kegiatan pengurangan dan penanganan sampah. Pengurangan sampah meliputi kegiatan $3 \mathrm{R}$ yaitu reuse, reduce, dan recycle, sedangkan kegiatan penanganan sampah meliputi pemilahan, pengumpulan, pengangkutan, pengolahan dan pemprosesan akhir.

Desa Tuananga merupakan salah satu desa yang berada di Kabupaten Sumbawa Barat, tepatnya di kecamatan Poto Tano. Desa Tuananga terletak di pedalaman sekitar pesisir pantai dan jauh dari jalan raya sehingga mempersulit truk pengangkut sampah masuk ke Desa Tuananga, yang menyebabkan sampah terus menumpuk di tempat pembuangan akhir yakni sungai. Sungai yang dimaksud adalah sungai kering yang hanya pada saat musim hujan saja dialiri air, hal ini yang menyebabkan sampah akan hanyut terbawa arus sungai hingga ke laut. Hal ini akan menyebabkan terjadinya pencemaran air.

Hal ini mendorong penulis menjalankan program daur ulang sampah plastik untuk dijadikan barang yang berguna dan bernilai jual berupa meja belajar yang bagian atas mejanyanya berbahan dasar sampah melalui program Kampung Lestari.

\section{Metode}

Terdapat 2 metode pelaksanaan kegiatan yaitu kegiatan pembuatan dan kegiatan pemasaran. Pada kegiatan pembuatan meja belajar bagian atasnya berbahan plastik oleh tim KKN Era New Normal Desa Tuanangan terdiri dari 2 tahap, yaitu tahap persiapan dan tahap pelaksanaan.

1. Tahap Pelaksanaan

a. Menghubungi Mitra

Pada hari selasa 29 Desember 2020 tim KKN New Normal Universitas Mataram menghubungi mitra ke kediamannya di Desa Tuananga Kecamatan Poto Tano Kabupaten Sumbawa Barat. Beberapa hal yang dibahas selama menghubungi mitra yaitu menentukan jadwal kegiatan sosialisasi bersama mitra dan juga masyrakat setempat, penyediaan alat dan bahan untuk kegiatan sosialisasi pembuatan meja berbahan dasar plastik.

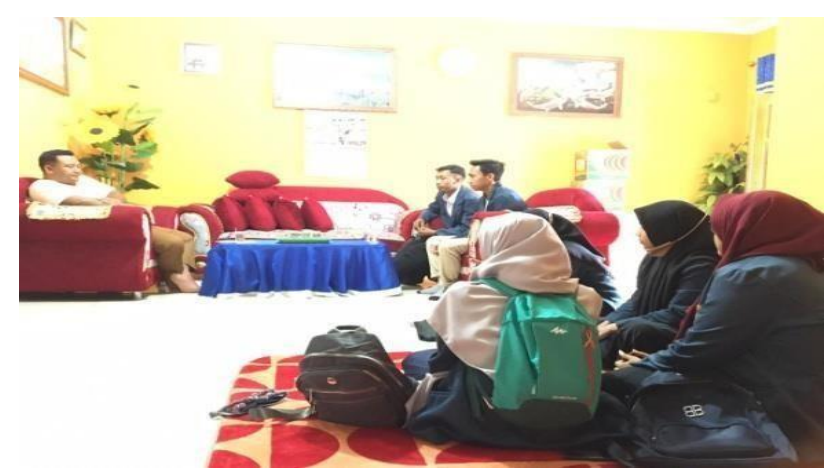

Gambar 1. Menghubungi Mitra

\section{b. Menentukan jadwal kegiatan sosialisasi} dengan mitra 
Berdasarkan kesepakatan yang telah dicapai dengn pihak mitra, jadwal kegiatan sosialisasi pembuatan meja belajar berbahan dasar plastik dilaksanakan pada hari jum'at, 1 Januari 2020.

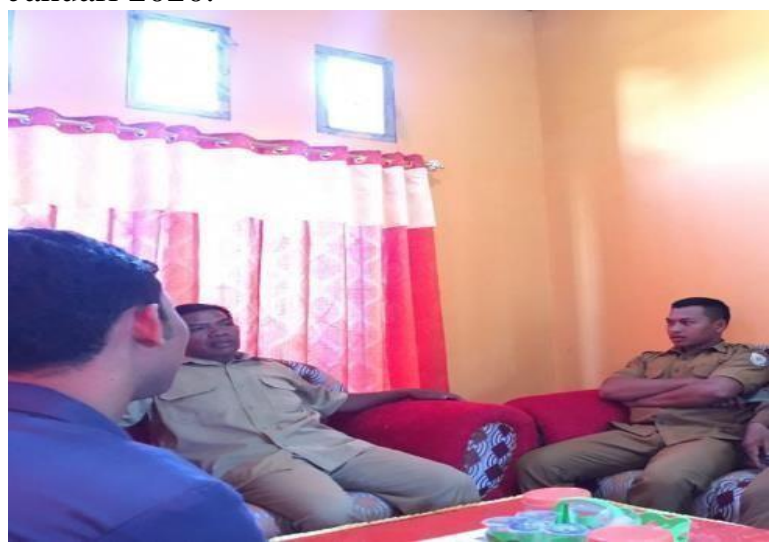

Gambar 2. Penentuan jadwal sosialisasi dengan mitra dan masyarakat sekitar

\section{c. Menyiapkan alat dan bahan pembuatan meja berbahan dasar plastik}

Alat-alat yang diperlukan dalam pembuatan meja belajar berbahan dasar plastik yaitu, gunting, open, mesin las, cetakan bagian atas meja, dan gergaji. Sedangkan bahan yang diperlukan yaitu plastik, resin, katalis,besi, dan pigmen resin.

\section{Tahap Pelaksanaan}

Tahap pelaksanaan dilaksanakan pada hari jum'at, 1 Januari 2020. Kegiatan dilaksanakan di Kantor Desa Tuananga.

a. Tahap Pertama Sebelum memberikan sosialisasi tentang cara pembuatan meja belajar berbahan dasar plastik, terlebih dahulu masyarakat Tuananga diberikan pengetahuan pengetuan dasar tentang efek dari sampah dan kondisi Kabupaten Sumbawa Barat dalam menghasilkan sampah dibandingkan dengan kabupaten-kabupaten yang ada di Provinsi Nusa Tenggara Barat, manfaat mendaur ulang plastik terhadap lingkungan, dan dapat dijadikan usaha yang berkelanjutan. Pada tahap ini, yang bertindak sebagai pemateri yaitu tim KKN Era New Normal Universitas Mataram.

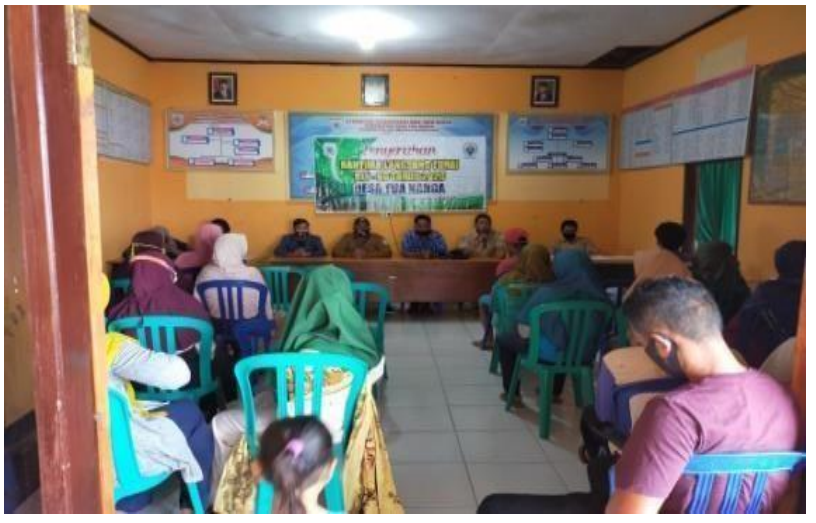

Gambar 3. Sosialisasi program pengelolaan sampah plastik

\section{b. Tahap Kedua}

Setelah pemateri menjelaskan tentang manfaat dari pembuatan meja berbahan dasar plastik, kegiatan selanjtnya yaitu tim KKN Era New Normal

Universitas Mataram bersama mitra dan masyarakat Desa Tuananga membuat bagian atas meja berbahan dasar plastik. Langkah-langkahnya sebagai berikut:

- Persiapkan alat dan bahan pembuatan bagian atas meja berbahan dasar plastik .

- Menggunting plastik menjadi potongan dengan ukuran kecil.

- Kemudian potongan plastik berukuran kecil dimasukkan ke dalam open selama 8 menit guna menghilangkan merek yang terdapat pada plastik.

- Masukkan potongan plastik berukuran kecil yang sudah di open ke dalam wadah bagian atas meja.

- Bentuk pola sesuai dengan pola yang diinginkan.

- Campurkan resin dan katalis, perbandingan $1: 100$.

- Tuangkan resin dan katalis yang sudah dicampurkan ke dalam wadah yang terdapat potongan plastik berukuran kecil yang sudah di open hingga menutupi semua potongan plastik.

- Tunggu sampai hingga resin dan katalis mengeras.

- Bagian atas meja telah jadi dan siap dihias dan dimodifikasi sesuai keinginan.

\section{Tahap Pemasaran Produk}

Tindak lanjut dari pembuatan meja belajar berbahan dasar plastik yaitu pemasaran produk. Pemasaran meja belajar berbahan dasar plastik dilakukan oleh tim KKN Era New Normal Universitas Mataram dan mitra. Tim Era New 
Normal Universitas Mataram memasarkan produk dengan strategi yang digunakan untuk promosi yaitu secara online dengan menggunakan sosial media Facebook dan endorse. Membuat sosial media facebook pribadi KKN kelompok Kampung Lestari Desa Tuananga. Endorse adalah strategi kedua dalam promosi yang dilakukan penjual dengan meminta tokoh terkenal yaitu sahabat dan rekan untuk mempromosikan produk.

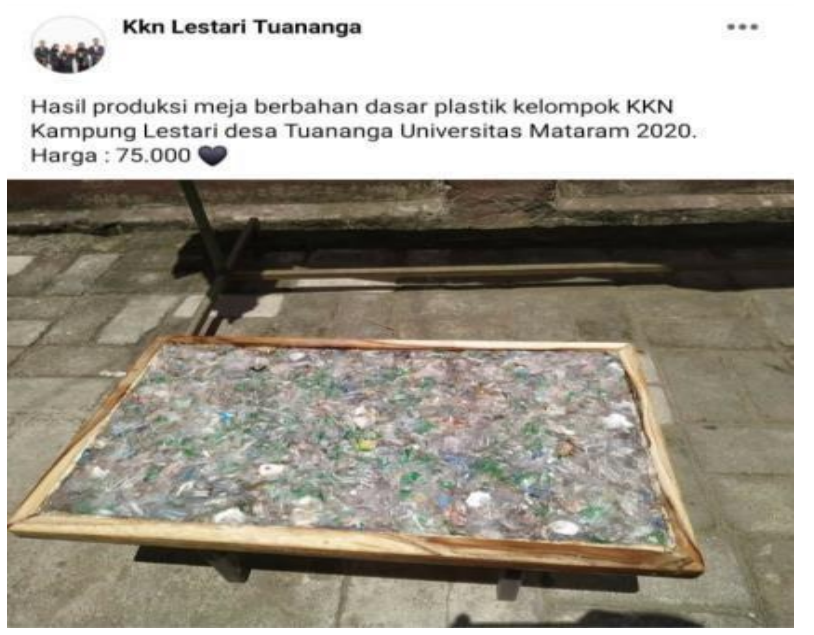

Gambar 4. Pemasaran produk di sosial media

\section{Hasil dan Pembahasan}

Suatu program pengelolaan kebersihan lingkungan, khususnya sampah tidak akan dapat berjalan dengan optimal jika hanya mengandalkan pemerintah saja. Pengenalan dan penerapan prinsip 3R (Reduce, Reuse, Recycle) atau pengurangan, penggunaan kembali, dan daur ulang sampah, merupakan salah satu cara pendekatan sumber dalam pengelolaan sampah (Kementerian Pekerjaan Umum, 2010). Dengan konsep ini masyarakat tidak hanya membuang sampah tapi sekaligus memanfaatkannya menjadi barang yang bernilai jual tinggi. Sudah saatnya masyarakat mengubah paradigma sampah dari barang yang tidak berguna menjadi sesuatu yang bernilai jual tinggi dan dapat dimanfaatkan.Pengelolaan sampah yang paling sederhana seperti memisahkan sampah organik dan anorganik di masyarakat merupakan kunci awal penerapan konsep 3R.

Pengabdian masyarakat yang dilaksanakan oleh tim KKN Universitas Mataram Era New Normal di Desa Tua Nanga yang berlangsung selama 45 hari. Selama kegiatan pengabdian masyarakat, Tim KKN Universitas Mataram Era
New Normal memperoleh data tentang inovasiinovasi yang dilakukan oleh masyarakat Tua Nanga dalam mengelolah sampah plastik melalui pembagian kuisioner tentang pengelolaan sampah yang dilakukan oleh masyarakat Desa Tua Nanga.

Kegiatan sosialisasi tentang pemanfaatan sampah plastik kepada mitra dan masyarakat Desa Tua Nanga oleh tim KKN Universitas Mataram Era New Normal berjalan dengan lancar. Kegiatan yang dihadiri oleh mitra dan beberapa masyarakat Desa Tua Nanga. Kegiatan dibuka oleh ketua tim KKN, kemudian penyampaian materi di sampaikan oleh ketua dan anggota tim lainnya. Sebelum kegiatan sosialisasi dilaksanakan, peserta kegiatan dibagikan leaflet produk yang berisi fakta timbulan sampah di Kabupaten Sumbawa Barat, tujuan, dan proses pembuatan produk bagian atas meja berbahan dasar plastik.

Peserta kegiatan sosialisasi yaitu mitra dan beberapa masyarakat Desa Tua Nanga sebelumnya belum pernah mengetahui salah satu inovasi dari pengelolaan sampah plastik, mereka hanya mengetahui bahwa sampah plastik hanya dapat dijual kepada pembeli barang-barang bekas sehingga dapat menghasilkan uang. Setelah kegiatan sosialisasi, hasilnya peserta kegiatan menjadi termotivasi untuk meneruskan inovasi baru pengelolaan sampah plastik yaitu pembuatan bagian atas meja berbahan dasar plastik.

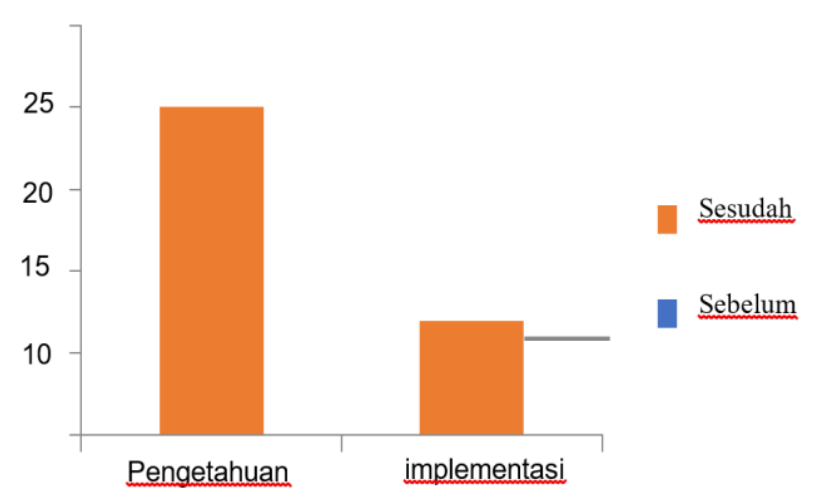

Gambar 5. Grafik Sosialisasi

Berdasarkan grafik di atas diperoleh data berupa pengetahuan sebelum dan sesudah sosialisasi. Serta implementasi tentang inovasi pengelolaan sampah di Desa Tua Nanga setelah dilaksanakannya kegiatan sosialisasi. Ada 20 orang peserta sosialisasi tentang upaya pengelolaan sampah plastik menjadi inovasi 
pengelolaan sampah bernilai jual. Diperoleh data setelah melaksanakan sosialisasi tentang pengetahuan warga sekitar tentang inovasi dalam pengelolaan sampah. Dari 20 orang koresponden, terdapat peningkatan pengetahuan sebanyak $100 \%$ dari sebelum dan sesudah pelaksaan sosialisasi. Dengan tingkat implementasi sebanyak 35\%. Hal ini menunjukkan perkembangan yang cukup signifikan dari sebelum dan sesudah dilaksanakan sosialisasi pengelolaan sampah.

Peminat pembuatan bagian atas meja berbahan dasar plastik masih sangat sedikit bahkan tidak ada di wilayah Kabupaten Sumbawa barat dan bahan dasar dari pembuatan produk ini sangat mudah ditemukan dikarenakan sampah plastik akan selalu dihasilkan oleh masyarakat. Oleh karena itu, kami megajak peserta sosialisasi untuk bersama-sama dalam meningkatkan ekonomi kreatif dan meminimalisir pencemaran lingkungan oleh limbah plastik di Desa Tua Nanga yaitu terkait dengan pembuatan bagian atas meja berbahan dasar plastik.

\section{Kesimpulan}

Pembuatan bagian atas meja berbahan dasar plastik dari tim KKN Universitas Mataram Era New Normal merupakan sebuah inovasi baru dalam pengelolaan sampah plastik menjadi barang yang bernilai jual tinggi. Bahan dasar dari produk ini sangat mudah diperoleh, jadi masyarakat Desa Tua Nanga bisa dengan mudah membuat sendiri bagian atas meja berbahan dasar plastik tanpa perlu mengeluarkan biaya yang banyak dalam proses pembuatannya.

Inovasi pembuatan bagian atas meja berbahan dasar plastik dapat memberikan ide kreatif kepada masyarakat Desa Tua Nanga untuk menjadikan produk ini sebagai peluang usaha yang diharapkan dapat membuka peluang usaha dan meningkatkan ekonomi masyarakat. Melalui inovasi ini juga dapat memberikan dampak positif bagi lingkungan yang dapat meminimalisir terjadinya pencemaran lingkungan oleh sampah plastik.

\section{Ucapan Terima Kasih}

Kegiatan pengabdian ini merupakan bagian dari kegiatan KKN mahasiswa dari Universitas Mataram di Era New Normal yang bekerja sama dengan mitra dari kantor Desa Tua Nanga dalam penyelenggaraannya. Kegiatan dilaksanakan dengan melibatkan banyak pihak terkait khususnya tukang las besi dan tukang kayu selaku pihak yang membantu dalam pembuatan meja belajar yang bagian atasnya berbahan dasar plastik. Sehingga kegiatan ini dapat berlangsung tanpa kendala yang berarti.

\section{Daftar Pustaka}

Kementerian Pekerjaan Umum. (2010). Modul Pengolahan Sampah Berbasis 3R. Badan Penelitian Dan Pengembangan - Pusat Penelitian Dan Pengembangan Permukiman.

Paeno, Kasmad Dkk. 2020. Pemanfaatan Sampah Plastik Untuk Kerajinan Rumah Tangga Taman Belajar Kreatif Mekar Sari. Jurnal Pengabdian Pada Masyarakat : Vol. 2 Nomor 1. Halaman 57-61 https://dislhk.ntbprov.go.id/2020/10/21/dat a -perkiraan-timbulan-sampah-provinsintb/ diakses pada 5 Januari 2021 